ELORE (ISSN 1456-3010), vol. 19 - 2/2012.

Julkaisija: Suomen Kansantietouden Tutkijain Seura ry.

[http://www.elore.fi/arkisto/2_12/keinanen.pdf]

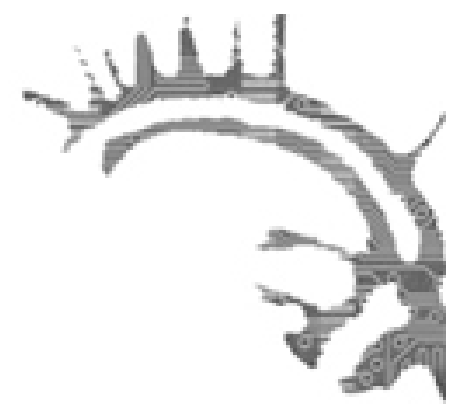

\title{
RECENSION
}

\section{FINSK, SVENSK ELLER SVERIGEFINSK?}

\section{FINSKHETEN FÖR ANDRA GENERATIONENS FINNAR I SVERIGE}

WECKSTRÖM, LOTTA 2011: Representations of Finnishness in Sweden. Helsinki: Finnish Literature Society. 171 sidor.

\section{Marja-Liisa Keinänen}

Den finländska massmediala bilden av sverigefinnarnas tillvaro har sedan 1960-talet präglats av ett starkt eländesperspektiv. Dokumentärserien Kansankodin kuokkavieraat (Folkhemmets snyltgäster), som sändes av YLE förra året, visar hur djuprotad den ensidigt negativa synen på sverigefinnarnas situation fortfarande är. Serien, och inte minst dess rubrik, har väckt upprörda känslor hos den sverigefinska TV-publiken, som varken känner sig som "snyltare" eller som gäster på tillfälligt besök i grannlandet. Den negativa massmediala bilden av sverigefinnar bygger dock på föråldrade, stereotypa uppfattningar om sverigefinnar och deras status i dagens Sverige och tycks inte ha påverkats av de förändringar som skett under de senaste femtio åren. Från att ha varit en invandrargrupp med relativt låg status i 1960-talets Sverige, utgör den sedan dryga tio år en av de fem nationella minoriteterna i Sverige. Under 2000-talets lopp har sverigefinnarnas minoritetsposition också på olika sätt institutionaliserats, vilket bland annat innebär att det har inrättats finskspråkiga förvaltningsområden som berättigar invånarna till en viss samhällsservice på finska. Hittills har runt fyrtio kommuner anslutit sig till dessa områden. Vad gäller den tidigare forskningen om sverigefinnar har även den varit starkt prob- 
Marja-Liisa Keinänen: Finsk, svensk eller sverigefinsk?

lem- och konfliktorienterad. Fenomenet är emellertid inte nytt. Detta synsätt har även präglat forskningen om sverigefinnarnas betydligt tidigare föregångare, skogsfinnarna, som bosatte sig i Mellersta Skandinavien under perioden 1580-1650 och stod i fokus för den finska forskningen under första halvan av 1900-talet. Dagens minoritetsforskning ställer sig dock kritisk till den ensidiga, problem- och konfliktorienterade synen, som tidigare dominerat forskningen om den sverigefinska minoriteten och har sökt på ett mer nyanserat sätt belysa migrationsprocesser och deras komplexitet. Lotta Weckströms aktuella språksociologiska avhandling, som fokuserar på andra generationens finnar i Sverige och deras uppfattningar om finskhet, placerar sig i den här nya och mer nyanserade inriktningen av migrationsforskning. Syftet med Weckströms arbete är att undersöka vad den finska bakgrunden och finskheten betyder för andra generationens sverigefinnar. Hennes avhandling utgör ett viktigt bidrag till den nordiska etnicitetsforskningen minst i två avseenden: dels för att sverigefinnarna - trots att de utgör den största migrantgruppen i Sverige - har varit en högst osynlig och understuderad grupp, dels för att det finns ytterst få undersökningar om andra generationens sverigefinländare. I det avseendet bidrar Weckströms studie till synliggörande av den sverigefinska minoriteten i allmänhet och den andra generationen sverigefinnar i synnerhet.

\section{ANdra generationens finnar i Mellersta Sverige}

Weckströms avhandling, som huvudsakligen baseras på intervjumaterial och fältobservationer, undersöker informanternas tal om finskhet och söker ringa in de områden där finskheten manifesterar sig i deras vardagliga liv i Sverige. För det andra studeras de intervjuades tal om språkrelaterade frågor och den roll som olika språk, främst finskan och svenskan, spelar i deras liv. Studien avhandlar även den ytterst väsentliga frågan om hur viktigt det egna språket är för en minoritet och dess överlevnad. En central fråga är således huruvida den finska identiteten baseras på språket och om den som inte talar finska kan räknas som finne. Språkfrågan har hög aktualitet eftersom det finska språkets fortsätta existens, trots sin status som ett nationellt minoritetsspråk, upplevs som hotad då språkkunskaperna radikalt har minskat generation för generation. Till sist, behandlas frågan om hur man definierar en invandrare och vilka som räknas in i den så kallade andra generationen.

Inledningsvis definierar författaren en andra generations sverigefinne som en person som har minst en finsktalande förälder. Hon har intervjuat sammanlagt 29 personer, som på ett eller annat sätt identifierar sig som finnar, varav tio utsågs till nyckelinformanter. Det framgår inte av avhandlingen vilken sammansättning gruppen i sin helhet hade bara nyckelinformanternas bakgrund och bostadsort presenteras närmare. Vi vet dock att majoriteten av de intervjuade är kvinnor, eftersom männen som tillfrågades avstod från att medverka. Informanterna söktes upp genom den så kallade snöbollsmetoden: den första informanten kontaktade sina kompisar och kompisars kompisar. Detta är ett vanligt tillvägagångssätt vid intervjustudier men det förs sällan någon diskussion kring insamlingsteknikens betydelse för gruppens sammansättning och därigenom för 
Marja-Liisa Keinänen: Finsk, svensk eller sverigefinsk?

materialets utformning. Inte heller Weckström diskuterar de konsekvenser som det aktuella urvalet av informanter eventuellt haft för undersökningsresultatet, till exempel för utkristalliseringen av de teman som avhandlingen senare kom att kretsa kring. Men det faktum att samma teman återkom i intervjuerna - bara sätten att prata om dem varierade - tyder på att materialet nått den mättnadsnivå som förutsätts av en tillförlitlig kvalitativ studie. Min avsikt är inte att ifrågasätta temanas relevans, men det hade varit viktigt med ett resonemang kring urvalet av informanter och studieorter - författaren bedrev ju fältarbete på tre olika platser i Mellansverige - och hur detta urval eventuellt påverkat slutresultatet. Det är nämligen möjligt att delvis andra teman hade dykt upp eller att tonvikten i materialet hade hamnat annorstädes om man till exempel hade haft fler manliga informanter eller informanter från multietniska förorter i storstäderna. Det är rimligt att anta att representationer av finskhet ter sig olika i mer etniskt homogena småstäder och i mångkulturella förorter i storstäder där flerspråkighet och flerkulturella tillhörigheter är en självklar del av människornas vardag.

Samtidigt är det viktigt att notera att författaren är helt medveten om de begränsningar som den här typen av kvalitativa metoder innebär, och påpekar i slutdiskussionen att hennes studie enbart har fångat upp några röster bland hundratals andra möjliga, men understryker att dessa ändå utgör en substantiell provkarta på andra generationens stämmor. Det är en slutsats som jag finner högt befogad.

\section{ANDRA GENERATIONEN OCH FINSKHET}

Genom en analys av vad Weckström kallar för finskhetens representationsrepertoarer har hon extraherat olika sätt att tala om finskhet samt ett antal teman som regelbundet återkommer i intervjuerna. Dessa två repertoarer som avhandlingen kretsar kring handlar om "språk och samhälle" och "annorlundahet". Finska språket har ett viktigt symbolvärde för Weckströms informanter och fungerar som den viktigaste markören för finskhet. Detta kommer tydligt fram även i intervjusituationerna. Alla intervjuade ansåg att svenskan var deras starkaste språk, men de flesta föredrog ändå finskan som intervjuspråk, vilket bekräftar Weckströms konstaterande att även intervjusituationen fungerar som en arena för identitetskonstruktion. Detta kan naturligtvis innebära problem för studieresultaten, eftersom internationell etnicitetsforskning tydligt visar att intervjuspråket och intervjuarens etnicitet påverkar de intervjuades svar i frågor kring etnicitet, vilket författaren också påpekar. Tillämpat på Weckströms studie skulle det innebära att de intervjuade framhävde sin finskhet och tonade ned det svenska inför intervjuaren som är av finländsk härkomst och anger finska som sitt starkaste språk. Frågan problematiseras inte i metodavsnittet, men författaren är medveten om denna problematik och reflekterar fortlöpande över sin roll i kunskapsproduktionen.

Enligt Weckström förknippar informanterna det finska språket starkt med den privata sfären, medan svenskan är språket som används ute i samhället, till exempel $i$ arbetslivet. Men man skulle också kunna hävda att det åtminstone i de intervjuades barndom fanns en finskspråkig offentlighet, även om rätt begränsad och marginaliserad. Den bestod 
Marja-Liisa Keinänen: Finsk, svensk eller sverigefinsk?

av finskspråkiga institutioner: daghem, skolor eller skolklasser samt församlingar och föreningar. Trots att många av informanterna gått dagis och skola på finska ser de ändå finskan som en strikt privat angelägenhet, vilket innebär att det åvilar familjen att se till att barnen lär sig finska. Några ställer sig även kritiska till den nya möjligheten att få viss typ av samhällsservice på finska, eftersom de själva inte är i behov av det. Om dessa attityder är vanligt förekommande hos andra generationens finnar, har de finska förvaltningskoordinatorer som söker synliggöra det finska språket till exempel genom skyltar på finska och finskspråkig information, en tuff arbetsuppgift framför sig.

Språket är alltså den viktigaste symbolen för finskhet, men finskheten yttrar sig i informanternas berättelser även som vissa föreställda karaktärsdrag, till exempel mod, hög arbetskapacitet och -moral. Informanterna associerar även vissa sporter med det finska. Det är dock något förvånande att finsk matkultur inte tycks inta någon framträdande plats i informanternas berättelser, fast det enligt mina erfarenheter är ytterst centralt för finskheten hos sverigefinnar. Även Weckströms första fälterfarenheter pekar på matens vikt, eftersom hon inför sin fältresa handlade ljusrostat kaffe och länkkorv till sin värdfamilj, som visserligen tillhörde första generationen sverigefinnar.

Weckström nämner att hon till en början var tveksam till att lyfta fram negativa företeelser i sitt material, såsom alkoholmissbruk, eftersom hon på det sättet riskerade att bekräfta negativa stereotyper om finnar. Men hon valde att ta med temat i analysen eftersom alla intervjuade tog upp alkoholvanorna. Man måste naturligtvis iaktta försiktighet när man lyfter fram negativa aspekter som kan bidra till gruppens stigmatisering, men informanternas diskussioner om sverigefinnars förmenta alkoholmissbruk är nog inte av den karaktären att det i dag skulle kunna skada gruppens anseende. På grund av etiska hänsynstaganden blir den delen av analysen en aning onyanserad, eftersom fokus hamnar på alkoholmissbruk, medan den sverigefinska alkoholkulturen, som även den torde fungera som en viktig identitetsmarkör, inte belyses.

\section{LIK MEN ÄNDÅ ANNORLUNDA}

Den andra representationsrepertoaren som står i centrum för Weckströms analys handlar om att vara annorlunda, det vill säga om diskursiv konstruktion av skillnader och gränser mellan grupper. Identiteten konstitueras ju genom skillnadsskapande vilket sker relationellt i interaktion med signifikanta andra. Detta kapitel är särskilt intressant då det visar hur intrikat processen för skillnadsskapande blir för grupper som i de flesta avseenden är rätt lika varandra. Det är ju antagligen denna kulturella likhet som är en av orsakerna till att kulturforskarna åtminstone i Sverige varit så ointresserade av den sverigefinska minoriteten.

Som redan nämnts är språket den viktigaste faktorn som skiljer den sverigefinska gruppen från majoritetsbefolkningen. Men även om språket har ett viktigt symboliskt värde för de intervjuade, betraktas språkkunskaperna inte som helt avgörande för den finska identiteten. Finskheten för dem som inte talar finska kan också yttra sig som en stark känsla av finskhet. Känslans betydelse framgår tydligt i en intervju där den inter- 
Marja-Liisa Keinänen: Finsk, svensk eller sverigefinsk?

vjuade konstaterar: "Jag låter som en svensk och ser ut som en svensk men känner mig finsk" (s. 156). Weckströms rön om känslans betydelse för identiteten är viktig och kan även bidra till förståelsen av identitetsskapande hos grupper som lever på gränsen till assimilering. Som ett exempel kan nämnas skogsfinnarna i Norge, som har lyckats behålla sin skogsfinska identitet och har till och med uppnått en status som nationell minoritet i Norge, trots att språket dog ut i 1900-talets början och man inte på något tydligt sätt skiljer sig från sin norska omgivning.

Weckströms diskussion kring multipla identiteter utgör ett viktigt bidrag till forskningen om sverigefinnar. Såsom hon understryker tenderar etnicitetsdiskurserna att utgå från en strikt dikotomisk modell som bara erbjuder individen en subjektposition: man är antingen finsk eller svensk, inte både och. När informanterna ombads att definiera sig själva i termer av etnicitet tvekade många, vilket i ett traditionellt perspektiv skulle kunna tolkas som ett tecken på en osäker identitet. Weckström väljer dock att tolka de intervjuades osäkerhet som ett tecken på att den gängse tolkningsmodellen är för snäv. Informanternas sätt att resonera kring sina identiteter ryms inte in en strikt bipolär modell. Deras sätt att se på sig själva kan bäst beskrivas i termer av hybriditet, vilket öppnar för möjligheten till multipla identiteter. Eftersom identitet även skapas situationellt, aktualiseras olika identiteter i olika situationer, vilket innebär att man faktiskt kan vara både finsk och svensk, sverigefinsk, finsksvensk eller Rinkebybo, västeråsare och så vidare.

I det sista avsnittet diskuterar Weckström hur hennes avhandling eventuellt bidragit till minoritetsforskningen men även till allmänhetens förståelse av minoritets- och migrationsfrågor. Förutom det som framkommit ovan vill jag lyfta fram ytterligare två aspekter. Den ena rör frågan om man som minoritetsforskare bör söka stärka identiteten hos den grupp man studerar. Jag tar inte här någon principiell ställning i frågan utan nöjer mig med att konstatera att Weckströms avhandling gör det genom att på ett nyanserat och mångsidigt sätt belysa den sverigefinska minoritetens levnadsvillkor och att hon därigenom bekämpar förlegade, stereotypa uppfattningar om gruppen. För det andra, bidrar boken till interkulturell förståelse genom att visa att det finns en mångfald av sätt att vara finne/finländare på i dagens Sverige - och i Finland.

Filosofie doktor Marja-Liisa Keinänen arbetar som minoritetsforskare vid Hugo Valentin-centrum vid Uppsala universitet och som universitetslektor vid Stockholms universitet. 